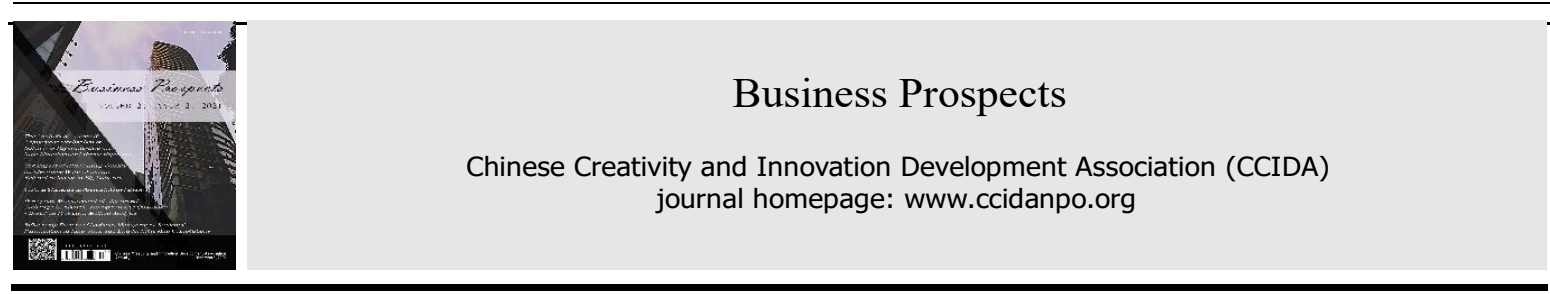

https://doi.org/10.52288/bp.27089851.2021.12.03

\title{
An Empirical Study on the Influence of Asset-backed Securitization on the Profitability and Liquidity of Commercial Banks of China
}

\author{
Di-Chuan Yang ${ }^{1,}$ * \\ ${ }^{1}$ Associate Professor of School of International Business, Xiamen University Tan Kah Kee College \\ * Correspondence: $511482777 @ q q . c o m$
}

Received: 2021.05.23; Accepted: 2021.10.20; Published: 2021.12.01

\begin{abstract}
This paper uses the panel data of Chinese commercial banks to analyze the impact of credit assetbacked securitization on the profitability and liquidity of Chinese commercial banks. The results show that there is a significant negative correlation between asset-backed securitization and the profitability of commercial banks in China. The main reason for this phenomenon is that China's credit asset-backed securitization is still in the pilot stage. The main purpose of asset-backed securitization is not to improve the level of profitability, but to broaden the financing channels, in addition, the high transaction cost of assetbacked securitization is also an important reason. However, there is no significant correlation between assetbacked securitization and the liquidity of commercial banks in China. The reason is that although asset-backed securitization can make the future income of banks cash in advance, considering the efficiency of capital use and the rationality of assets and liabilities, banks will use these funds to make new loans, which reduces the liquidity of banks.
\end{abstract}

Keywords: Asset-backed Securitization; Bank Profitability; Bank Liquidity

\section{Introduction}

Asset-backed securitization is an important financial innovation in the 20th century. Its main innovation is to connect the direct financing and indirect financing markets. Since the 1980s, asset-backed securitization, together with traditional equity financing and debt financing, has been known as the three main means of financing for more than 40 years.

China's asset-backed securitization began to pilot in 2005, but the global financial tsunami in 2008 brought China's pilot to an abrupt end. After that, with the need of financial deepening in China, China started the pilot of asset-backed securitization again in 2012. According to different regulatory agencies, asset-backed securitization in China can be divided into three modes: credit asset securitization, enterprise asset securitization and asset-backed notes. The main originator of credit asset-backed securitization is China's commercial banks. From the experience of foreign commercial banks in developing credit asset-backed securitization, the development of asset-backed securitization can improve the profitability of commercial banks, revitalize the existing assets of banks, and increase the stability of banks and the liquidity of assets. But what is the impact of asset-backed securitization on the profitability and liquidity of commercial banks in China is unified understanding. The main reason is that the time for China's banks to carry out asset securitization business is relatively short, and the relevant data is difficult to obtain. Therefore, most of the existing studies on the impact of asset securitization on commercial banks mainly use foreign data. Although it brings some difficulties to the writing of this paper, it also provides space for innovation. 


\section{Literature Review}

\subsection{Asset-backed Securitization and Bank Profitability}

On the relationship between asset-backed securitization and commercial bank profitability, scholars in China and abroad have conducted extensive research. As early as 1999, Thomas found that asset securitization can create huge wealth for bank shareholders, and each asset securitization can increase the income of bank shareholders by about 5\% (Thomas, 1999). Pavel and Phillis (1987) believe that asset securitization can improve the financial leverage of banks and save regulatory tax to improve the return on assets of banks. Jiangli et al. (2007) build a monitoring-based banking model in which banks can finance through debt, equity, loan sales and asset securitization. Through the model, they found that when banks finance through asset securitization, their profitability is higher, and according to the way of securitization, the higher the leverage, the lower the risk of bankruptcy. After that, Jiangli and Pritsker (2008) used the data of Bank of America from 2001 to 2008 to empirically analyze the impact of asset securitization on bank bankruptcy risk, profitability, and leverage. The results show that asset-backed securitization can reduce the risk of bankruptcy, increase leverage and bank profitability. Casu et al. (2013) used the data of American commercial banks before the crisis to empirically analyze whether asset securitization improves the performance of American banks. They found that asset securitization can indeed improve the performance level of banks, but asset securitization can also improve the credit risk exposure of banks. In addition, they also found that although asset securitization makes bank financing more diversified, it also increases bank financing costs. In domestic research, Zou et al. (2015) used the quarterly data of American commercial banks from 2001 to 2012 to conduct empirical research, and analyzed the impact of asset securitization activities on the return on equity of commercial banks and the impact path. They found that the intensity of asset securitization is positively correlated with the return on equity of commercial banks. The main reason is that the higher the intensity of asset securitization, the higher the leverage ratio and asset turnover rate of banks, and the lower the income and profit margin, thus improving the return on net assets. Cao (2017) used the annual data of listed banks in China from 2012 to 2016 to study the impact of asset securitization on the profitability of banks in China by quoting Loutskina's "bank loan portfolio liquidity" index. The result shows that credit asset securitization has no significant impact on the profitability of large banks in China, but has a positive impact on the profitability of small banks. Song and Xiao (2018) used the panel data of China's commercial banks from 2012 to 2017 to construct a dynamic panel model to study the impact of asset securitization on the profitability of China's banks. The study found that the profitability of China's commercial banks declined due to the development of credit asset securitization.

\subsection{Asset Securitization and Bank Liquidity}

On the impact of asset securitization on the liquidity of commercial banks, scholars at home and abroad have also conducted extensive research. Obey (2000) used an empirical model to prove that asset securitization can improve the profitability and liquidity level of commercial banks. On this basis, he proposed a method for banks with poor profitability to improve their profitability and management efficiency through credit asset securitization. Loutskina and Strahan (2006) found that securitization reduced the impact of bank financial status on loan supply. Low-cost financing and increased balance sheet liquidity increase the willingness of banks to approve difficult to sell mortgage loans (large mortgage loans), but have no effect on the willingness of banks to approve easy to sell mortgage loans (non-large mortgage loans). Therefore, securitization promotes the depth of the secondary mortgage market and reduces the impact of local capital shocks on credit supply. In terms of extension, securitization weakens the relationship between bank financing conditions and credit supply decentralization, thus reducing the actual effect of monetary policy. Loutskina (2011) further studied the role of asset securitization in bank management. He proposed a new "liquidity index of bank loan portfolio". Through the new index, he found that asset securitization helps banks transform illiquid loans into liquid funds, and improves banks' lending ability, but it also makes bank loans less sensitive to the cost of capital. Yao et al. (2012) used the panel data of Bank of America and Granger causality test to study the effect of bank credit asset securitization. They found that asset securitization can improve the capital adequacy ratio of banks, reduce financing costs, and enhance profitability and efficiency. However, the effect of reducing liquidity risk and improving the quality of loan portfolio is not obvious. Li et al. (2016) used the data of Bank of America to study the impact of asset securitization on the liquidity, loan supply and stability of banks of different sizes. They found that for small banks, loan portfolio liquidity is poor, and the marginal effect of asset securitization on liquidity risk management is greater than that of large banks; for large banks, due to the high liquidity of loan 
portfolio, the marginal effect of securitization on loan expansion is greater than that of small banks. But whether large or small banks, asset securitization can improve the risk level of banks and increase the stability of banks by improving the liquidity of assets. Liu and Li (2013) used the data of Bank of America to make an empirical analysis on the profitability, security, and liquidity of banks. The results show that: (1) for smaller banks, the higher the degree of asset securitization, the higher the level of profitability, but for larger banks, the higher the degree of asset securitization, the lower the level of profitability. (2) Asset securitization can improve the asset liquidity of banks of all sizes, but for the sake of the rationality of assets and liabilities, banks will usually reduce the proportion of liquid assets after asset securitization, resulting in the higher degree of asset securitization, the lower the ratio of liquid assets.

\section{Research Methods}

\subsection{Panel Data Model}

This paper uses panel data of commercial banks to study the impact of asset-backed securitization on the profitability and liquidity of commercial banks. Panel data (also known as longitudinal data) is a twodimensional structural data that extends the time series to the spatial direction or the section data to the practical direction. The panel data econometric model is one of the important development of econometrics in the past 20 years. Panel Data Econometrics has made as much use of sample information as possible. There are two models that are built by panel data: fixed effect and random effect regression model. The difference between individuals in fixed effect model is fixed and can be expressed by a series of constants; the difference of Jiading individuals in stochastic effect model is subject to a random distribution, which can be expressed by a random variable.

\subsection{The Selection of Variables and Regression Equation}

In this paper, when choosing explanatory variables or control variables, the method of stepwise regression is adopted. Firstly, the explanatory variables are determined. Then, the optimal regression model is selected by increasing, reducing or replacing variables, and referring to the fitting degree of fixed effect and random effect panel regression model. This can minimize the occurrence of multiple collinear problems. The following are the explanatory variables, explanatory variables, and control variables I selected:

Explained variable-Because the main research of this paper is the influence of credit asset-backed securitization on the profitability and liquidity of commercial banks in China, there are two explanatory variables: (1) the profit level of a bank is expressed by the return on net assets of a bank (air), that is, the proportion of net profit of a bank in a certain period to measure the bank's profit level. (2) As an alternative variable of bank liquidity, lar is the ratio of liquidity assets to total assets in a certain period of a bank to measure the liquidity level of a bank (Because of the need of research, later lar is also used as explanatory variable).

Explanatory variable-We use asset securitization ratio (SAR) as the agent variable of the degree of assetbacked securitization of commercial banks. The so-called asset securitization ratio refers to the ratio of loans of a bank to the total assets in a certain period. The higher the ratio of securitization loans to total assets of a bank, the deeper the securitization degree of the bank's assets. According to Loutskina (2005), it is believed that asset securitization can enhance the liquidity of bank balance sheet, because asset securitization can help banks to convert non-current loans into securities with good liquidity. The ability of bank securitization has become an integral part of liquidity risk management of banks. At the same time, the external financing cost of banks with more securitization asset portfolios is lower than that of other banks with more non-current asset portfolios. Although it increases the credit supply of banks, it also reduces the sensitivity of bank asset portfolio to traditional financing sources (such as deposits).

Control variables-In addition, some important control variables are considered in this paper, which are net interest income ratio, bank size, equity to asset ratio and non-performing loan ratio.

(1) Net interest income ratio (NIR). The net interest income ratio refers to the ratio of net interest income of commercial banks to total assets of banks in a certain period. The higher net interest income means that it has stronger ability to obtain income from bank loans. It is expected that the coefficient of return of net interest on two dependent variables can be positive and negative.

(2) The size of the bank. In China, the large scale of banks means that its business is comprehensive, the risk control system is also relatively sound, and its liquidity assets are large. Therefore, the liquidity level is relatively high. Therefore, it is expected that the bank size has an impact on the profitability and liquidity of the 
bank, but further research is needed to study whether the positive effect or negative effect is specific. This paper takes the sum of total assets of banks to represent the size of the bank (LNT).

(3) Ratio of equity to total assets (EAR). Bank is a highly leveraged industry. Among all assets of the bank, only equity belongs to the shareholders' money. Therefore, the greater the proportion of equity is, the greater the loss of shareholders is when the bank is at risk, whether it is credit risk, liquidity risk or operational risk, so the bank's operating condition has a greater incentive to shareholders. Therefore, the shareholders of the bank will strengthen the supervision of credit through institutional arrangement and organization improvement, which will affect the profitability, stability, and liquidity of the bank.

(4) Non performing loan rate (NLTR). According to the requirements of the CBRC, the bank needs to divide the loans into five types of loans: normal, concerned, subordinated, doubtful and loss, among which the latter three types of loans are non-performing loans of banks. According to the number of five types of loans, banks need to make provision of $1 \%, 2 \%, 25 \%, 50 \%$ and $100 \%$, respectively. Therefore, the amount of nonperforming loan ratio directly affects the profitability of the bank and indirectly affects liquidity.

Regression equation. According to panel data analysis method, we construct random effect model and fixed effect model respectively to study the influence of credit asset securitization on commercial banks' profitability and liquidity. The regression equation is as follows:

Random effect model:

$$
\begin{aligned}
& \operatorname{AIR}_{\text {it }}=\beta_{11} \times \mathrm{SAR}_{\text {it }}+\beta_{12} \times \mathrm{LAR}_{\text {it }}+\beta_{13} \times \mathrm{EAR}_{\text {it }}+\beta_{14} \times \mathrm{NLTR}_{\text {it }}+\mathrm{b}_{1}+\mu_{1 \mathrm{i}}+\varepsilon_{1 \mathrm{it}} \\
& \mathrm{LAR}_{\mathrm{it}}=\beta_{21} \times \mathrm{SAR}_{\mathrm{it}}+\beta_{22} \times \mathrm{NIAR}_{\mathrm{it}}+\beta_{23} \times \mathrm{NLTR}_{\mathrm{it}}+\beta_{24} \times \mathrm{LNT}_{\text {it }}+\mathrm{b}_{2}+\mu_{2 \mathrm{i}}+\varepsilon_{2 \mathrm{it}}
\end{aligned}
$$

Fixed effect model:

$$
\begin{aligned}
& \operatorname{AIR}_{\text {it }}=\beta_{11} \times \mathrm{SAR}_{\text {it }}+\beta_{12} \times \mathrm{LAR}_{\text {it }}+\beta_{13} \times \mathrm{EAR}_{\text {it }}+\beta_{14} \times \mathrm{NLTR}_{\text {it }}+\mathrm{c}_{1 \mathrm{i}}+\varepsilon_{1 \mathrm{it}} \\
& \mathrm{LAR}_{\text {it }}=\beta_{21} \times \mathrm{SAR}_{\mathrm{it}}+\beta_{22} \times \mathrm{NIAR}_{\text {it }}+\beta_{23} \times \mathrm{NLTR}_{\text {it }}+\beta_{24} \times \mathrm{LNT}_{\text {it }}+\mathrm{c}_{2 \mathrm{i}}+\varepsilon_{2 \mathrm{it}}
\end{aligned}
$$

\subsection{Data Sources}

China's asset-backed securitization pilot started in 2005, but the global financial tsunami suspended the pilot in 2008, and it was not gradually restored until 2012. When the pilot in 2012 and 2013 just resumed, there were fewer banks issuing asset securitization, and the credit asset securitization was not mature, resulting in the observation data discontinuity. Therefore, this paper selects the data from 2014 to 2018 . In addition, according to the division of CIRC, China's commercial banks are mainly divided into five state-owned banks, national joint-stock commercial banks, urban commercial banks, and rural commercial banks. Among these banks, only five state-owned banks and national joint-stock commercial banks belong to national large and medium-sized banks, with standardized operation, comprehensive business, and sound risk control system. At present, the development of credit asset securitization market in China is still relatively short, so the banks issuing asset securitization are mostly large and medium-sized banks, and asset securitization has become the normal business of many large and medium-sized banks. However, urban commercial banks and rural commercial banks are mostly regional small and medium-sized banks, the operation system is not perfect, the risk control system is weak compared with large and medium-sized banks. Because urban commercial banks and rural commercial banks are regional banks, according to the different regions, in terms of loans, they need to serve the local enterprises according to the local economic that results in very different situation. From the perspective of the development of credit asset securitization in China, most urban commercial banks and rural commercial banks either did not develop asset securitization business, or only pilot one or two asset securitization, and did not take asset securitization as a normal business. The impact of asset securitization on urban commercial banks and rural commercial banks is not representative. Therefore, this paper mainly selects 10 banks with large asset securitization issuing scale from the five major state-owned banks and national joint-stock banks as samples. The data of banks are from 2014-2018 annual report, and the data of asset securitization of each bank is mainly from Wind information database. 


\section{Empirical Analysis}

In order to study the impact of credit asset securitization on the profitability and liquidity of commercial banks, we first make descriptive statistics of each explanatory variable, explanatory variable, and control variable, and then make empirical analysis.

\subsection{A Study on the Effect of Asset Securitization on Bank Profitability}

Table 1 shows the descriptive statistics of explanatory variables, explanatory variables, and control variables of 10 banks in China. The average value of return on equity (AIR) of explanatory variables is $15.5470 \%$, the average value of asset securitization ratio (SAR) of explanatory variables is $0.2435 \%$, the average value of liquidity ratio of control variables (LAR) is $47.35 \%$, the average value of equity to total assets (EAR) is $7.03 \%$, and the average non-performing loan ratio (NLTR) is $1.55 \%$. Because the regression mechanism of panel data with fixed effect and random effect is different, this paper selects several important statistical indexes of EViews in regression estimation to illustrate the problem.

Table 1. Descriptive statistical structure of each variable.

\begin{tabular}{cccccc}
\hline & $\begin{array}{c}\text { Explained } \\
\text { variable }\end{array}$ & $\begin{array}{c}\text { Explanatory } \\
\text { variable }\end{array}$ & \multicolumn{3}{c}{ Control variable } \\
\cline { 2 - 6 } & AIR & SAR & LAR & EAR & NLTR \\
\hline Average & 0.1555 & 0.0024 & 0.4736 & 0.0703 & 0.0155 \\
Standard error & 0.0038 & 0.0004 & 0.0201 & 0.0019 & 0.0004 \\
Median & 0.1514 & 0.0015 & 0.4731 & 0.0702 & 0.0153 \\
Standard deviation & 0.0267 & 0.0028 & 0.1422 & 0.0132 & 0.0029 \\
Variance & 0.0007 & 0.0000 & 0.0202 & 0.0002 & 0.0000 \\
Kurtosis & -0.6039 & 4.1126 & 8.9185 & 11.5635 & 1.5937 \\
Skewness & 0.3759 & 1.9608 & 2.1221 & -0.7310 & 0.7284 \\
Region & 0.1004 & 0.0128 & 0.8579 & 0.1104 & 0.0137 \\
Minimum value & 0.1117 & 0.0000 & 0.2861 & 0.0108 & 0.0102 \\
Maximum & 0.2121 & 0.0128 & 1.1441 & 0.1212 & 0.0239 \\
\hline
\end{tabular}

According to the results of Hausman test, the fixed effect model is selected. It can be seen from Table 2 that the coefficient of SAR is -2.2927 , and the corresponding P-value is 0.0315 , indicating that the test result is significant at the significance level of $5 \%$. Because the coefficient of SAR is negative, the degree of asset securitization is negatively correlated with the profitability of commercial banks, which indicates that the higher the degree of asset securitization, the lower the profitability of commercial banks. There may be three reasons: first, asset securitization in China is still in the pilot stage. The main purpose of asset securitization business of commercial banks is not to make profits, but to develop a new financing channel. In order to prevent default of asset-backed securities, commercial banks usually take out relatively high-quality assets. It is packaged and sold through securitization. Secondly, the transaction costs of asset securitization in China are also relatively high. For example, in asset securitization, commercial banks need to hire securities companies to guide banks to select assets and underwrite asset-backed securities. They also need to hire accounting firms to audit assets and other credit institutions to enhance the credit of asset-backed securities. This has increased the cost of bank asset securitization. Finally, asset securitization will become a normal business for many users in the future. In order to carry out asset securitization more efficiently, many banks are building infrastructure such as asset securitization system, and the construction of infrastructure such as asset securitization system is also an expensive expense. Therefore, the current securitization of credit assets in China can only help banks transfer part of credit risk rather than bring book profits to commercial banks in the short term. 
Table 2. Regression results of the impact of the degree of credit asset securitization on the profitability of commercial banks.

\begin{tabular}{cccccc}
\hline & Coefficient & Salue & $\begin{array}{c}\text { Standard } \\
\text { deviation }\end{array}$ & T-statistics & P-value \\
\hline \multirow{2}{*}{$\begin{array}{c}\text { Fixed effect } \\
\text { model }\end{array}$} & C & 0.2315 & 0.0291 & 7.9480 & 0.0000 \\
& SAR & -2.2927 & 1.0244 & -2.2381 & 0.0315 \\
& LAR & 0.0593 & 0.0347 & 1.7097 & 0.0959 \\
& EAR & -0.1962 & 0.2700 & -0.7269 & 0.4720 \\
& NLTR & -5.4506 & 1.1190 & -4.8709 & 0.0000 \\
\hline & R-squared & 0.7328 & & & 0.0000 \\
Random effect & C & 0.2462 & 0.0267 & 9.2137 & 0.1070 \\
model & SAR & -1.5475 & 0.9409 & -1.6446 & 0.2537 \\
& LAR & 0.0260 & 0.0225 & 1.1562 & 0.1798 \\
& EAR & -0.2925 & 0.2147 & -1.3624 & 0.0000 \\
\hline
\end{tabular}

\subsection{Research on the Influence of Asset Securitization on Bank Liquidity}

Table 3 shows the descriptive statistics of explanatory variables, explanatory variables and control variables. According to the Hausman test results, the fixed effect model is selected. It can be seen from Table 4 that the SAR coefficient is 4.4680 , but the test results are not significant. This shows that the influence of asset securitization on the liquidity level of commercial banks is not significant. Loutskina (2005) believes that asset securitization can enhance the liquidity of bank balance sheet because asset securitization can help banks transform illiquid loans into securities with good liquidity. The ability of bank securitization has become an integral part of bank liquidity risk management. However, this study does not reach the same conclusion. The reason may be that the essence of asset securitization is to make the future cash flow of commercial banks cash in advance. Although this can temporarily improve the liquidity of banks, for the sake of capital profitability and asset liability rationality, commercial banks will reuse the funds obtained from asset securitization financing for loans as soon as possible. This, in turn, has rapidly reduced the liquidity level of banks. Therefore, it cannot be concluded that asset securitization will effectively improve the liquidity level of commercial banks in China.

Table 3. Description statistics of each variable.

\begin{tabular}{cccccc}
\hline & $\begin{array}{c}\text { Explained } \\
\text { variable }\end{array}$ & $\begin{array}{c}\text { Explanatory } \\
\text { variable }\end{array}$ & \multicolumn{3}{c}{ Control variable } \\
\cline { 2 - 6 } & LAR & SAR & NIAR & NLTR & LNT \\
\hline Average & 0.4736 & 0.0024 & 0.0055 & 0.0155 & 11.3952 \\
Standard error & 0.0201 & 0.0004 & 0.0002 & 0.0004 & 0.1076 \\
Median & 0.4731 & 0.0015 & 0.0054 & 0.0153 & 11.1167 \\
Standard deviation & 0.1422 & 0.0028 & 0.0015 & 0.0029 & 0.7611 \\
Variance & 0.0202 & 0.0000 & 0.0000 & 0.0000 & 0.5792 \\
Kurtosis & 8.9185 & 4.1126 & 15.1148 & 1.5937 & -0.5355 \\
Skewness & 2.1221 & 1.9608 & 2.9392 & 0.7284 & -0.2473 \\
Region & 0.8579 & 0.0128 & 0.0103 & 0.0137 & 3.2439 \\
Minimum value & 0.2861 & 0.0000 & 0.0033 & 0.0102 & 9.2878 \\
Maximum & 1.1441 & 0.0128 & 0.0135 & 0.0239 & 12.5318 \\
\hline
\end{tabular}


Table 4. Regression results of the impact of credit asset securitization on the liquidity of commercial banks.

\begin{tabular}{cccccc}
\hline & & Coefficient value & Standard deviation & T-statistics & P-value \\
\hline \multirow{2}{*}{$\begin{array}{c}\text { Fixed effect } \\
\text { model }\end{array}$} & C & 3.6439 & 1.1483 & 3.1734 & 0.0031 \\
& SAR & 4.4680 & 3.0991 & 1.4417 & 0.1580 \\
& NIAR & 29.4418 & 15.0301 & 1.9589 & 0.0579 \\
& NLTR & 4.6417 & 3.6899 & 1.2579 & 0.2165 \\
& LNT & -0.2997 & 0.0956 & -3.1369 & 0.0034 \\
\hline \hline \multirow{2}{*}{ Random effect } \\
model & R-squared & 0.9199 & & & 0.0000 \\
& CAR & 1.8502 & 0.2250 & 8.2233 & 0.6440 \\
& NIAR & -1.2766 & 2.7442 & -0.4652 & 0.0000 \\
& NLTR & -2.1201 & 6.7966 & 5.0617 & 0.4956 \\
\hline & LNT & -0.1343 & 3.0861 & -0.6870 & 0.0000 \\
\hline
\end{tabular}

\section{Conclusion}

Asset-backed securitization is an innovative financial product. In the United States and other developed countries, asset securitization has a history of more than 40 years. It is mature for commercial banks to manage their assets, liabilities and risks through asset securitization. The pilot of asset securitization in China started in 2005. Due to the global financial tsunami in 2008, the pilot of asset securitization was suspended for four years until 2012. Therefore, China's commercial banks in how to use asset securitization on the bank's asset liability management and risk management is still in the stage of exploration. This is also the conclusion of panel regression with the data of Chinese commercial banks is different from that of foreign data.

Due to the limited data, this paper only studies the impact of asset securitization on the profitability and liquidity of Chinese commercial banks. The results show that: (1) The degree of credit asset securitization is negatively correlated with the profitability of Chinese commercial banks. This means that the deeper the degree of asset securitization, the lower the profitability of banks. The main reason is that the credit asset securitization of commercial banks is still in the pilot stage. The main purpose of asset securitization of banks in China is not to improve the profitability, but to broaden the financing channels. In addition, the transaction cost of asset securitization in China is relatively high, which is also an important reason for the decline of bank profitability. (2) The relationship between the degree of credit asset securitization and the liquidity level of Chinese commercial banks is not significant. This may be the reason that although asset securitization can make the future income of the bank cash in advance, considering the efficiency of the use of funds and the rationality of assets and liabilities, the bank will use these funds to make new loans, which reduces the liquidity of the bank.

Fund Project: Xiamen University Tan Kah Kee College scientific research incubation project: Research on the impact of asset-backed securitization on the operation and management of China's commercial banks under the new economic normal (YY2019W02).

\section{References}

1. Cao, B. (2017). Research on the Impact of Asset Securitization on the Profitability of My Country’s Commercial Banks. Macroeconomic Research, 5: 7-7.

2. Casu, B., Clare, A., Sarkisyan, A., \& Thomas, S. (2013). Securitization and Bank Performance. Journal of Money, Credit and Banking, 45(8): 1617-1658.

3. Gao, B., Zhang, M., \& Zou, X. M. (2016). Asset Securitization and Bank Operation Stability: Impact Mechanism, Impact Stage and Crisis Impact. Nankai Economic Research, 4: 17-37.

4. Jiangli, W., \& Pritsker, M. (2008). The Impacts of Securitization on U.S. Bank Holding Companies. Social Science Electronic Publishing.

5. Jiangli, W., Pritsker, M., \& Raupach, P. (2007). Banking and Securitization. Social Science Electronic Publishing.

6. Li, Z. H., Huang, L., \& Li, C. W. (2016). The Impact of Asset Securitization on the Liquidity, Loan Supply and Stability of Banks. Financial Economics Research, 31(3): 3-15.

7. Liu, Q. L., \& Li, F. Y. (2013). Asset Securitization and Liquidity, Profitability and Risk Level of Bank Assets. Financial Forum, 5: 35-44. 
8. Loutskina, E. (2005). Does Securitization Affect Bank Lending? Evidence from Bank Responses to Funding Shocks. Manuscript.

9. Loutskina, E. (2011). The Role of Securitization in Bank Liquidity and Funding Management. Journal of Financial Economics, 100(3): 663-684.

10. Loutskina, E., \& Strahan, P. E. (2006). Securitization and the Declining Impact of Bank Finance on Loan Supply: Evidence from Mortgage Originations. Journal of Finance, 64(2): 861-922.

11. Obey, L. (2000). Financial Innovation in the Banking Industrial: The Case of Asset Securitization. New York: Garland Publishing Inc.

12. Pavel, C. A., \& Phillis, D. (1987). Why Commercial Banks Sell Loans: An Empirical Analysis. Economic Perspectives, 11(May): 3-14.

13. Song, Q. H., \& Xiao, X. H. (2018). Statistics and Decision-making of the Impact of Credit Asset Securitization on Commercial Banks' Profitability. Empirical Analysis, 34(24): 172-176.

14. Thomas, H. (1999). A Preliminary Look at Gains from Asset Securitization. Journal of International Financial Markets Institutions and Money, 9(3): 321-333.

15. Yao, L. S., Wang, X., \& Ning, X. (2012). Empirical Study on the Securitization Effect of Bank Credit Assets-Based on Panel Data of American Banking. International Financial Research, 9: 71-78.

16. Zou, X. M., Zhang, M., \& Gao, B. (2015). Asset Securitization and Commercial Bank Profitability: Relevance, Impact Path and Crisis Impact. World Economy, 38(11): 144-167.

(Editor: Jiahua Yang) 